\title{
Nutritional Quality of Biscuit Supplemented with Wheat Bran and Date Palm Fruits (Phoenix dactylifera L.)
}

\author{
Gamal A. El-Sharnouby ${ }^{1 *}$, Salah M. Aleid ${ }^{2}$, Mutlaq M. Al-Otaibi ${ }^{1}$ \\ ${ }^{1}$ Department of Food and Nutrition Sciences, College of Agricultural and Food Sciences, King Faisal University, Al-Ahsa, Saudi \\ Arabia; ${ }^{2}$ Date Palm Research Centre of Excellence, King Faisal University, Al-Ahsa, Saudi Arabia. \\ Email: ${ }^{*}$ Gamali59@yahoo.com
}

Received October $9^{\text {th }}, 2011$; revised December $21^{\text {st }}, 2011$; accepted December $29^{\text {th }}, 2011$

\begin{abstract}
Fruits of date palm (Phoenix dactylifera L.) are consumed throughout the world and are a vital component of the diet in most Arabian countries. The effect of partial replacement of wheat flour with a 1:1 mixture of wheat bran and date palm fruit powder on rheological properties of the biscuit dough was studied. Levels of mixture used were $10 \%, 20 \%, 30 \%$ and $40 \%$. Dough rheology (farinograph, extensograph properties) and biscuit quality (physical properties, colour, sensory evaluation) were assessed. Results obtained indicated that water absorption gradually increased by increasing the levels of wheat bran: palm date powder, meanwhile mixing tolerance index decreased. Dough stability, which indicates the dough strength, also found to decrease by increasing mixture of wheat bran and date powder (1:1). Furthermore, dough development time gradually increased by increasing the mixture at all levels. It was 6.04 min at level of $40 \%$ compared to the control $(2.5 \mathrm{~min})$. Extensograph results showed that dough energy and dough resistance to extension and proportional number also increased compared with control sample. The proportional number (R/E) ratios increased largely from 3.20 to 5.27 at the level of $40.0 \%$. Ash and fibre contents gradually increased as the mixture levels increased. However, mineral content progressively increased by increasing the level of date powder in the mixture. Incorporation of wheat bran and date powder mixture decreased the spread of the biscuits from 55.66 to $52.82 \mathrm{~mm}$ without change in the thickness of the biscuits. Organoleptic properties revealed that quality of biscuits was acceptable at mixture level of $30 \%$.
\end{abstract}

Keywords: Wheat Flour; Wheat Bran; Palm Date Fruit; Biscuit Dough; Rheological Properties; Nutritional Quality

\section{Introduction}

The date palm (Phoenix dactylifera L.) is one of the oldest fruit trees in the Arabian Peninsula and has played an important role in day-to-day life of the people of this region for the last 7000 years [1]. Dates are known to be rich in carbohydrates $(80 \%)$ but quite low in protein $(2 \%$ - 3\%) [2] Dates are an excellent source of simple sugars, minerals and vitamins Lambiote, [3] with a fibre content of about $8 \%$ FAO, [4] and Lambiote, [3]. The flesh of a fully ripe date (Tamr) consists of two-third sugar and one-quarter water, the rest being mainly cellulose, pectin, ash and vitamins FAO [5] Therefore, the date considered as a nutritious fruit. Research has indicated the clear contribution of dates to human health when consumed with other food constituents, such as maintaining mineral and vitamin. Dates could also be a substitute for refined sugar Lambiote, [3] Researchers found that date consumption might be of benefit controlling glycaemia and lipid in diabetic patients [6] Furthermore, [7] evaluated the total

\footnotetext{
*Corresponding author.
}

phenolic content and the antioxidant activity of four date palm fruit varieties grown in Tunisia. They suggested that Tunisian date palm fruits may serve as a good source of natural antioxidants and could potentially be considered as a functional food ingredient. The measurements were taken at the "tamar" stage (the final stage of fruit ripeness). Date varieties were found to be rich in total phenolic content and antioxidant activity. However, most of the dates in Saudi Arabia are consumed at the Rutb and Tamr stages of maturity. Nevertheless, large quantities of surplus dates are dried and used for later consumption [8].

In recent years, the use of wheat and other cereal bran has gained importance in the formulation of various food products. Wheat bran is rich in protein $(\sim 14 \%)$, carbohydrates $(\sim 27 \%)$, minerals $(\sim 5 \%)$, fat $(\sim 6 \%)$ and B vitamins [9] and Kent and Evers [10]. In addition, it is cheap and readily available. There have been several attempts to incorporate bran from various sources into cereal products as a high protein and fibre source.

Many researchers [11], Hussin, [12] and [13] have re- 
ported experimental utilization of dates in different products (such as bakery products). It was found that replacement of sucrose by date paste in bread and cookies would improve their nutritional value by increasing levels of both minerals and vitamins. Most of the date sugars are invert sugar resulting in increasing the bread and cookie softness Hoseney, [14]. However, the utilization of date powder in bakeries and food products has not been reported. The objective of this study was:

1) To evaluate the effect of substituting wheat flour with different levels of (wheat bran: date powder, 1:1 $\mathrm{w} / \mathrm{w}$ ) on dough rheological properties.

2) To study the effect of supplementing wheat flour with 1:1 (w/w) of wheat bran and date powder on the nutritional value and quality of the produced biscuit.

3) To study the effect of supplementing wheat flour with 1:1 (w/w) of wheat bran and date powder on the overall acceptability of the produced biscuits.

Results from this study obtained would provide useful information on the utilization of date powder and wheat bran in manufacturing biscuit.

\section{Materials and Methods}

\subsection{Materials}

Date fruits (Rothana variety) cultivated in Saudi Arabia were obtained from Al-Hassa market at Tamr stage (about 18\% moisture). The date fruits were cleaned, pitted and the calyxes were removed. The dates were dried in oven under vacuum at $60^{\circ} \mathrm{C}$ for $10-12 \mathrm{hrs}$. The dried samples were cooled and ground in blender to tiny particles passing through 20 mesh sieve, i.e. similar to the size of wheat flour.

\subsubsection{Mixture Preparation}

Wheat flour (WF, 72\% extraction) and wheat bran (WB) were obtained from a commercial wheat flour company, Al-Hassa, Saudi Arabia.

The mixture of wheat bran (WB) and date powder (DP) was prepared at a ratio of 1:1 w/w. The mixture (WBDP $1: 1, \mathrm{~W} / \mathrm{W})$ were was thoroughly mixed, packed in plastic bags and stored in deep freezer until further work. 10\%, $20 \%, 30 \%$ and $40 \%$ of the mixture replaced wheat flour. The flour mixtures were individually blended and homogenized, then packed in polyethylene bags, tightly closed and kept in a deep freezer for further analysis and processing.

\subsubsection{Processing of Hard Sweet Biscuit}

Hard sweet biscuit was prepared by partially replacing the wheat flour $(72 \%$ extraction) with $10 \%, 20 \%, 30 \%$ and $40 \%$ of blends. The recipe of the biscuit was as follow: wheat flour or its blends, $350 \mathrm{~g}$; sucrose, $115 \mathrm{~g}$; shortening (palm oil), $50 \mathrm{~g}$; skimmed milk powder, $5 \mathrm{~g}$; high fructose (42 E.D.), $10 \mathrm{~g}$; ammonium bicarbonate, $5.5 \mathrm{~g}$; sodium bicarbonate, $2 \mathrm{~g}$; sodium metabisulfate, $0.10 \mathrm{~g}$ and vanillin extract, $0.04 \mathrm{~g}$. Preparation was as follows: Fat and sucrose firstly creamed by using a mechanical mixer for $10 \mathrm{~min}$. Sodium and ammonium bicarbonate dissolved in $100 \mathrm{ml}$ water were added to the prepared creamed mixture following by adding high fructose to the mixture. As creaming process was continued, flour, skimmed milk powder and vanillin extract were added and stirred well. The biscuit dough was sheeted to a thickness of $3.5 \mathrm{~mm}$, cut using a circular mould (51 mm dia.), and baked at $205^{\circ} \mathrm{C}$ for $9-10 \mathrm{~min}$. After baking, biscuits cooled to room temperature, packed in polypropylene pouches and sealed. The sugar in the biscuits formula adjusted to cater for the percentage of sugar present in the added date powder.

\subsection{Analytical Methods}

\subsubsection{Rheological Properties of the Blended Flour}

The rheological properties of the dough samples prepared by replacing wheat flour with 10\%, 20\%, 30\% and $40 \%$ mixture of wheat bran: date powder $(1: 1, w / w)$ were evaluated by the both Farinograph (Model: E-380, Brabender OHG, Duisburg, Germany) and Extensograph (Model: 8600 Brabender OHG, Duisburg, Germany). Dough produced from different blended flours was assessed for its farinograph and extensograph properties according to the method described by AACC [15]. Farinograph determined the effect of different levels of mixtures on dough rheology. Parameters measured were water absorption, dough development time, dough stability and mixing tolerance index. The elastic properties of dough with different levels of mixture were measured using the Extensograph. The parameters studied were resistance to extension $(\mathrm{R})$, extensibility $(\mathrm{E})$ and ratio figure $(\mathrm{R} / \mathrm{E})$.

\subsubsection{Chemical Analysis}

Percentages of moisture, crude protein, ether extract, total sugars (reducing and none reducing), crude fibre and ash were determined according to the method described by AOAC [16]. Furthermore, percentages of calcium, magnesium, iron, manganese, zinc and copper were also determined using the atomic absorption spectrophotometer (Perkin-Elmer Model 5000, Germany). Phosphorus was determined by spectro-photometer using molybdovandate according to the method described by AOAC [16]. Sodium and Potassium were determined by flame photometer (Corning 400, Serial No. 4889, UK).

\subsubsection{Theoretical Calculation of Energy}

The energy values were calculated theoretically using the following conversion factors $4.0,4.0$, and $9.0 \mathrm{kcal} / \mathrm{g}$ for protein, carbohydrates and fat, respectively, according to 
the method described by Paul and Southgate [17].

\subsubsection{Evaluation of Biscuits}

Physical characteristics: Diameter $(W)$ and Thickness $(T)$ of biscuits were measured by placing them edge-to-edge, stacking and measurements were made. The spread ratio $(W / T)$ was calculated. The objective evaluation of texture expressed as breaking strength (Kg, force) was measured using the triple beam snap (Three point break) technique of Gains [18], using an instron universal testing instrument (Model 4301, Instron Ltd., High Wycombe, Bucks, $\mathrm{UK})$.

\subsubsection{Colour Measurement}

Objective evaluation of surface colour $\left(L^{*}, a^{*}, b^{*}\right)$ for biscuit samples was measured using a UV-vis recording Spectrophotometer (Model UV 2100, Shimadzu Corporation, Kyoto, Japan) according to [19] with a reflectance attachment supported by an installed computer software. The values were calculated automatically and expressed in terms of colour difference $(\Delta \mathrm{E})$ and percent whiteness (W). This software calculated colour indices from spectra given by the spectrophotometer.

\subsubsection{Sensory Evaluation}

Biscuit samples in pouches coded with different numbers were presented to 6 trained panellists who were asked to rate each sensory attribute by assigning a score for surface colour (10), surface characteristics (10), crumb colour (10), taste (20), texture (20) and mouth feel (10) as described by [20].

\subsubsection{Statistical Analysis of Data}

The statistical analysis was conducted using the SAS package (SAS, 2003). The sensory analysis was statistically analysed. Duncan's Multiple Range Test was applied to assess significant differences between means at $5 \%$ level of probability Duncan, [21]. Each experiment (in triplicate) repeated at least twice and the values presented in terms of means \pm standard error SE [22].

\section{Results and Discussion}

\subsection{Chemical Characteristics of Wheat Flour, Wheat Bran and Date Powder}

Mean values for analysis of all samples are tabulated in Table 1. The moisture content of wheat flour and date powder was 11.4 and $11.0 \%$, respectively, and that of wheat bran sample was $8.2 \%$. Meanwhile, the moisture content of mixture of wheat bran: date powder (1:1) was $9.5 \%$. Ash content of wheat bran was $4.8 \%$ and that of all wheat flour and date powder was $0.5 \%$ and $2.6 \%$, respectively. Ash content of wheat bran and date powder mixture represented 3.8\% (Table 1). The fat content (ether extract) was in the range of $0.4 \%$ (date powder) to $3.6 \%$ (wheat bran) and protein content was $2.1 \%$ (date powder) to $14.0 \%$ (wheat bran). Dietary fibres were $15.4 \%$ (wheat bran), 9.4\% (date powder), $1.6 \%$ (wheat flour) and 12.3 $\%$ (wheat bran: date powder mixture). The total dietary fibre content (TDF) of wheat bran is an agreement with

Table 1. Chemical composition of raw materials used.

\begin{tabular}{lcccc}
\hline \multicolumn{1}{c}{ Components \% } & Wheat flour & Wheat bran & Date powder & Wheat bran: Date powder $(1: 1 \mathrm{w} / \mathrm{w})$ \\
\hline moisture & $11.4 \pm 0.04$ & $8.2 \pm 0.03$ & $11.0 \pm 0.02$ & $9.5 \pm 0.03$ \\
Ether extract & $1.0 \pm 0.03$ & $3.6 \pm 0.02$ & $0.4 \pm 0.03$ & $2.0 \pm 0.04$ \\
Crude protein & $10.5 \pm 0.05$ & $14.0 \pm 0.05$ & $2.1 \pm 0.03$ & $8.4 \pm 0.04$ \\
Crude fiber & $1.6 \pm 0.15$ & $15.4 \pm 0.13$ & $9.4 \pm 0.10$ & $12.3 \pm 0.10$ \\
Ash & $0.5 \pm 0.11$ & $4.8 \pm 0.18$ & $2.6 \pm 0.12$ & $3.8 \pm 0.10$ \\
Carbohydrates & $75.0 \pm 0.02$ & $54.0 \pm 0.04$ & $74.5 \pm 0.05$ & $64.0 \pm 0.03$ \\
Energy (kcal/100g) & $351.0 \pm 0.13$ & $304.4 \pm 0.20$ & $310.0 \pm 0.18$ & $306.0 \pm 0.16$ \\
Minerals (mg/100g) & & & & $62 \pm 0.04$ \\
Calcium & $15.0 \pm 0.02$ & $76.0 \pm 0.03$ & $49 \pm 0.05$ & $2.0 \pm 0.02$ \\
Sodium & $2.0 \pm 0.03$ & $2.0 \pm 0.03$ & $2.3 \pm 0.04$ & $875.0 \pm 0.09$ \\
Potassium & $107.0 \pm 0.10$ & $1182 \pm 0.11$ & $680 \pm 0.13$ & $5.6 \pm 0.04$ \\
Iron & $1.30 \pm 0.03$ & $10.6 \pm 0.04$ & $1.2 \pm 0.04$ & $540 \pm 0.12$ \\
Phosphorus & $108.0 \pm 0.11$ & $1013 \pm 0.13$ & $63 \pm 0.14$ & $4.0 \pm 0.11$ \\
Zinc & $0.6 \pm 0.06$ & $7.3 \pm 0.08$ & $0.3 \pm 0.14$ & $330.0 \pm 0.06$ \\
Magnesium & $20.0 \pm 0.01$ & $611.0 \pm 0.08$ & $43.0 \pm 0.07$ & $11.6 \pm 0.11$ \\
Manganese & $0.6 \pm 0.08$ & $11.5 \pm 0.11$ & $0.3 \pm 0.13$ & $1.6 \pm 0.06$ \\
copper & $0.1 \pm 0.06$ & $1.0 \pm 0.07$ & $0.2 \pm 0.06$ & \\
\hline
\end{tabular}

${ }^{*}$ calculated by difference Values are means \pm standard deviations $(\mathrm{n}=3)$. 
results obtained by [23,24]. Table 1 showed that high amounts of calcium, potassium, iron, phosphorus, zinc, magnesium and manganese were found in wheat bran, were 76.0, 1182.0, 10.6, 1013.0, 7.3, 611.0 and 11.5 $\mathrm{mg} / 100 \mathrm{~g}$ respectively. However, results obtained are in agreement with $[20,25]$.

\subsection{Rheological Properties of Flour Dough Samples Used}

\subsubsection{Farinograph Properties}

Farinograph data are shown in Figure 1. Water absorption increase in all samples as compared with control when the increasing the mixture of wheat bran: date powder (1:1) was increased up to $40 \%$. The results obtained were coincided with those of [26,27]. However, differences in water absorption were due to the greater number of hydroxyl group which exist in the fibre structure and allow more water interaction through hydrogen bonding [28]. The arrival time of all blended flours were similar in all samples $(1 \mathrm{~min})$ due to the differing levels of gluten arrival time and dough development may not be the same. Dough stability, which indicates the dough strength, was decrease when increasing mixture of wheat bran: date powder (1:1) compared with control (4.0 min); it was $8.3 \mathrm{~min}$ at level of $40.0 \%$, that was due to a reduction in gluten content. Furthermore, dough development time gradually increased by increasing wheat bran and date powder mixture at all levels, reaching $6.04 \mathrm{~min}$ at $40 \%$ substitution compared with control $(2.5 \mathrm{~min})$. Greater effects observed on the mixing tolerance index values. $[20,29,30]$ reported similar results for the addition of rye and wheat bran. The results showed the dough strength weakened with the increase in wheat bran: date powder addition.

\subsubsection{Extensograph Properties}

Regarding extensograph data, the effect of addition of mixture of wheat bran: date powder at varying levels on extensible properties is illustrated in Figure 2. The resistance to extension gradually increased in blends with increasing level of mixture of wheat bran: date powder. That was probably related to the interaction between

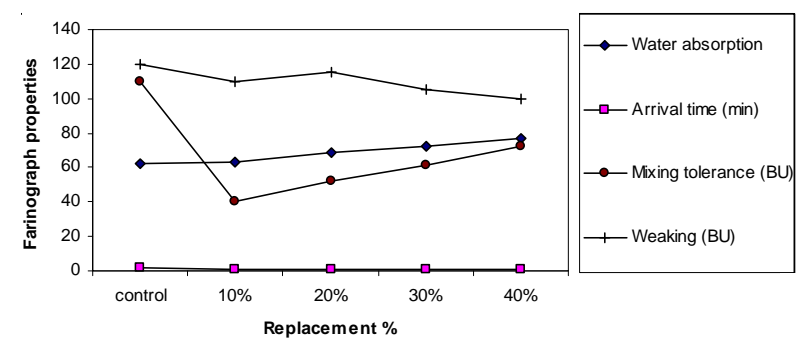

Figure 1. Effect of partial replacement by mixture of wheat bran: Date powder (1:1) on Farinograph properties.

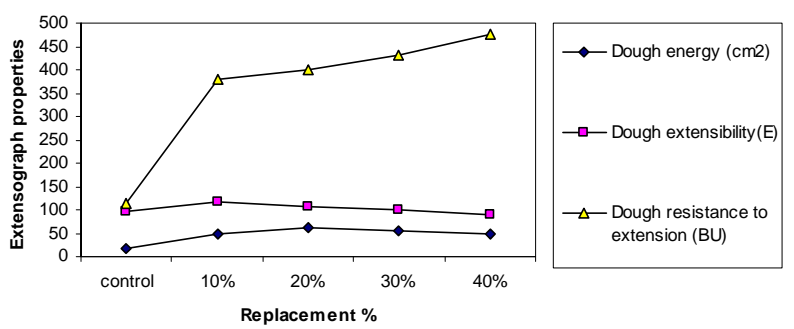

Figure 2. Effect of partial replacement by mixture of wheat bran: Date powder (1:1) on Extensograph properties.

polysaccharides and proteins from wheat flour as reported earlier by Jones and Erlander [31]. The extensibility values were greatly reduced by the addition of mixture of wheat bran: date powder. However, the ratio figure $(\mathrm{R} / \mathrm{E})$ increased with increasing level of mixture indicating the dough becoming harder in the presence of wheat bran. The proportional number $(\mathrm{R} / \mathrm{E})$ ratio values increased largely from 3.20 to 5.27 for $40.0 \%$ incorporation.

\subsection{Chemical Composition of Produced Biscuits}

The chemical components of biscuits made from flour blends were replaced with different levels 10,20, 30 and $40 \%$ of mixture of wheat bran and date powder $(1: 1)$ are shown in Table 2. The results indicated that there were slight increases in the moisture content as \% increasing the of mixture increased up to 40. Protein, ash and fibre gradually increased by increasing the percent of mixture of wheat bran and date powder. Carbohydrates slightly changed in all samples compared to the control. These results are in agreement with those reported by Abd El-lateef [20,32]. From Table 2, it could be concluded that as the levels of mixture increased in formula, the caloric value decreased in biscuits produced compared to the control sample.

\subsection{Mineral Content of Hard Sweet Biscuits Made from Wheat Flour, Wheat Bran and Date Powder}

The replacement effect of different levels of mixture wheat bran and date powder $(1: 1)$ on the mineral content of biscuits is shown in Table 2. Results showed that mineral progressively increased when levels of mixture were increased. Controls contained 18.20, 3.15, 104.58, 1.50, $113.56,0.84,26.54,0.81$ and $0.15 \mathrm{mg} / 100 \mathrm{~g}$ for calcium, sodium, potassium, iron, phosphorus, zinc, manganese and cupper, respectively. Meanwhile, at level of $40 \%$ of replacement, they increased to $46.87,4.21,470.2,348.0$, $365.7,2.54,160.0,3.96$ and 0.67 , respectively. It could be concluded that the addition of wheat bran and date powder mixture improved the mineral quality of biscuit. Therefore, that could partially provide children and 
Table 2. Proximate composition of supplemented biscuits (\%).

\begin{tabular}{|c|c|c|c|c|c|c|c|}
\hline $\begin{array}{c}\text { Supplementation } \\
\text { Level (\%) }\end{array}$ & Moisture & Fat & Protein & Fiber & Ash & Carbo-hydrate & $\begin{array}{c}\text { Caloric value } \\
\text { Kcal/100g }\end{array}$ \\
\hline Control (WF) & $3.81 \pm 0.13$ & $9.65 \pm 0.14$ & $8.64 \pm 0.15$ & $1.20 \pm 0.13$ & $0.56 \pm 0.12$ & $76.14 \pm 0.10$ & $425.97 \pm 0.18$ \\
\hline \multicolumn{8}{|l|}{ WF: WBDP \% } \\
\hline 90:10 & $3.85 \pm 0.20$ & $8.62 \pm 0.10$ & $9.14 \pm 0.23$ & $2.00 \pm 0.20$ & $0.92 \pm 0.10$ & $75.47 \pm 0.15$ & $416.02 \pm 0.12$ \\
\hline 80:20 & $3.97 \pm 0.23$ & $9.20 \pm 0.13$ & $9.66 \pm 0.25$ & $2.20 \pm 0.10$ & $1.00 \pm 0.20$ & $73.97 \pm 0.18$ & $417.32 \pm 0.16$ \\
\hline 70:30 & $4.00 \pm 0.11$ & $9.85 \pm 0.14$ & $10.16 \pm 0.13$ & $2.32 \pm 0.12$ & $1.20 \pm 0.16$ & $73.34 \pm 0.17$ & $422.65 \pm 0.14$ \\
\hline \multirow[t]{2}{*}{$60: 40$} & $3.86 \pm 0.09$ & $9.92 \pm 0.10$ & $10.63 \pm 0.13$ & $2.46 \pm 0.12$ & $1.26 \pm 0.08$ & $71.87 \pm 0.12$ & $419.28 \pm 0.11$ \\
\hline & \multicolumn{5}{|c|}{ Biscuit produced } & \multicolumn{2}{|c|}{ RDA* (mg/day) } \\
\hline \multirow{2}{*}{$\begin{array}{l}\text { Minerals content } \\
\quad(\mathrm{mg} / \mathbf{1 0 0 g})\end{array}$} & \multicolumn{5}{|c|}{ WF: WBDP ratio } & \multirow{2}{*}{ Children } & \multirow{2}{*}{ Adults } \\
\hline & WF control & $90: 10$ & $80: 20$ & $70: 30$ & $60: 40$ & & \\
\hline Calcium & $18.20 \pm 0.02$ & $25.30 \pm 0.04$ & $32.6 \pm 0.03$ & $39.00 \pm 0.05$ & $46.87 \pm 0.12$ & $500-800$ & $800-1200$ \\
\hline Sodium & $3.15 \pm 0.06$ & $3.45 \pm 0.06$ & $3.64 \pm 0.08$ & $3.95 \pm 0.13$ & $4.21 \pm 0.11$ & 1000 & 1500 \\
\hline Potassium & $104.58 \pm 0.09$ & $205.30 \pm 0.18$ & $295.70 \pm 0.16$ & $380.20 \pm 0.14$ & $470.20 \pm 0.13$ & 3000 & 3800 \\
\hline Iron & $1.50 \pm 0.03$ & $2.01 \pm 0.04$ & $2.54 \pm 0.02$ & $3.00 \pm 0.03$ & $348.00 \pm 0.011$ & $7-10$ & $10-15$ \\
\hline Phosphorus & $113.65 \pm 0.03$ & $170.22 \pm 0.05$ & $221.62 \pm 0.04$ & $290.40 \pm 0.06$ & $365.71 \pm 0.13$ & $460-500$ & $700-1250$ \\
\hline Zinc & $0.84 \pm 0.05$ & $1.23 \pm 0.08$ & $1.72 \pm 0.12$ & $2.11 \pm 0.07$ & $2.54 \pm 0.14$ & $3-5$ & $8-12$ \\
\hline Magnesium & $26.54 \pm 0.03$ & $60.21 \pm 0.04$ & $91.45 \pm 0.06$ & $125.61 \pm 0.07$ & $160.02 \pm 0.13$ & $80-170$ & $350-420$ \\
\hline Manganese & $0.81 \pm 0.03$ & $1.85 \pm 0.04$ & $2.73 \pm 0.05$ & $3.80 \pm 0.07$ & $3.96 \pm 0.12$ & $1.0-3.0$ & $2.0-2.3$ \\
\hline Copper & $0.15 \pm 0.04$ & $0.25 \pm 0.05$ & $0.34 \pm 0.07$ & $0.46 \pm 0.09$ & $0.67 \pm 0.16$ & 0.50 & $0.7-0.9$ \\
\hline
\end{tabular}

WF: wheat flour, WBDP: wheat bran: date powder (1:1) Values are means \pm standard deviations $(\mathrm{n}=3)$ *Recommended Dietary Allowances $(2004)$.

adults their daily requirements of potassium, phosphorus, calcium and iron by consuming these types of biscuit. The obtained results are in agreement with the results of $[33,34]$. However, while wheat bran may improve the absolute mineral contents of the respective products, due to increasing phytic acid content as well, the bioavailability and absorption of minerals may be decreased. Thus, such issues would need further evaluations in a separate study.

\subsection{Influence of Mixture of Wheat Bran and Date Powder on Physical Characteristics of Biscuits}

Biscuits prepared from 10\%, 20\%, 30\% and 40\% of mixture of wheat bran date powder (1:1) in the blends were evaluated for various physical and sensory characteristics. Incorporation of wheat bran and date powder mixture decreased the spread of the biscuits from 55.66 to $52.82 \mathrm{~mm}$ without larger changes in the thickness (Table 3). Hence, the spread ratio decreased from 8.28 to 7.88. Biscuits became harder as seen in the increase in breaking strength values from 1.32 to $2.11 \mathrm{~kg}$, especially at $30 \%$ and $40 \%$ levels were 2.00 and $2.10 \mathrm{~kg}$, respectively. Measurement of colour of the biscuits showed that the biscuit became darker with increasing level of wheat bran and date powder mixture. The obtained results are in complete agreement with those of [20].

\subsection{Sensory Evaluation of Produced Biscuits}

As shown in Table 4, colour of biscuits had low score as a result of increasing the level of date powder mixture. Above $30 \%$ date powder and wheat bran mixture in the formulation, biscuits had darker crumb colour and very hard texture. Taste and mouth feel of the biscuits were affected at levels $40 \%$ and $30 \%$ respectively. Biscuits had a dry mouth feel at level of $40 \%$. Meanwhile, at $10 \%$ mixture, the quality of the biscuits was not adversely affected. The colour, surface character, crumb colour, taste, texture and mouth feel of biscuits were acceptable at 30\% mixture. The obtained results are in an agreement with those of Leelavathi and Rao [20,35]. They reported that highly acceptable biscuits could be obtained by incorporating $30 \%$ of oat bran or $20 \%$ of barley bran in the formulation. 
Table 3. Physical characteristics of supplemented biscuits.

\begin{tabular}{ccccccc}
\hline $\begin{array}{c}\text { Supplem-entation } \\
\text { level (\%) }\end{array}$ & $\begin{array}{c}\text { Diameter }^{\mathrm{a}} \\
(W, \mathrm{~mm})\end{array}$ & $\begin{array}{c}\text { Thickness }^{\mathrm{a}} \\
(T, \mathrm{~mm})\end{array}$ & $\begin{array}{c}\text { Spread ratio }^{\mathrm{a}} \\
(W / T)\end{array}$ & $\begin{array}{c}\text { Breaking strength }^{\mathrm{Ab}} \\
(\mathrm{kg})\end{array}$ & $\begin{array}{c}\text { Whiteness }^{\mathrm{a}} \\
(\%)\end{array}$ & $\begin{array}{c}\text { Colour difference }^{\mathrm{a}} \\
(\Delta E)\end{array}$ \\
\hline Control (WF) & $55.66^{\mathrm{a}} \pm 0.20$ & $6.72^{\mathrm{a}} \pm 0.11$ & $8.28^{\mathrm{a}} \pm 0.21$ & $1.32^{\mathrm{a}} \pm 0.40$ & $17.00^{\mathrm{a}} \pm 0.14$ & $46.18^{\mathrm{a}} \pm 0.18$ \\
W: WBDP & & & & & & \\
& & & & & & \\
$90: 10$ & $55.20^{\mathrm{c}} \pm 0.24$ & $6.61^{\mathrm{a}} \pm 0.12$ & $8.35^{\mathrm{c}} \pm 0.25$ & $1.36^{\mathrm{b}} \pm 0.25$ & $16.70^{\mathrm{c}} \pm 0.16$ & $47.10^{\mathrm{b}} \pm 0.14$ \\
$80: 20$ & $54.30^{\mathrm{d}} \pm 0.28$ & $6.70^{\mathrm{a}} \pm 0.12$ & $8.10^{\mathrm{c}} \pm 0.29$ & $1.55^{\mathrm{c}} \pm 0.18$ & $13.52^{\mathrm{d}} \pm 0.12$ & $50.21^{\mathrm{c}} \pm 0.15$ \\
$70: 30$ & $53.50^{\mathrm{d}} \pm 0.28$ & $6.70^{\mathrm{a}} \pm 0.14$ & $7.99^{\mathrm{e}} \pm 0.20$ & $2.00^{\mathrm{d}} \pm 0.24$ & $13.41^{\mathrm{d}} \pm 0.19$ & $51.60^{\mathrm{d}} \pm 0.12$ \\
$60: 40$ & $52.82^{\mathrm{e}} \pm 0.29$ & $6.70^{\mathrm{a}} \pm 0.15$ & $7.88^{\mathrm{e}} \pm 0.24$ & $2.10^{\mathrm{d}} \pm 0.20$ & $11.27^{\mathrm{e}} \pm 0.15$ & $53.70^{\mathrm{c}} \pm 0.14$ \\
SEM $^{\mathrm{B}}( \pm)$ & 0.21 & 0.085 & 0.10 & 18.50 & 0.10 & 0.11 \\
\hline
\end{tabular}

Values for a particular column followed by different letters differ significantly $(\mathrm{P}<0.05)$. Values are means \pm standard deviations $(\mathrm{n}=4)$; ${ }^{\mathrm{A}}$ objective measurement. ${ }^{\mathrm{B}}$ Standard error of mean at ${ }^{\mathrm{a}} 45$ degrees of freedom, ${ }^{\mathrm{b}} 153$ degrees of freedom.

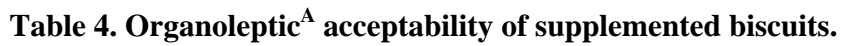

\begin{tabular}{|c|c|c|c|c|c|c|c|}
\hline $\begin{array}{c}\text { Supplement-ation level } \\
(\%)\end{array}$ & $\begin{array}{l}\text { Colour } \\
(10)\end{array}$ & $\begin{array}{l}\text { Surface character } \\
\text { (10) }\end{array}$ & $\begin{array}{c}\text { Crumb Colour } \\
(10)\end{array}$ & $\begin{array}{l}\text { Taste } \\
(20)\end{array}$ & $\begin{array}{l}\text { Texture } \\
(20)\end{array}$ & $\begin{array}{l}\text { Mouth feel } \\
(10)\end{array}$ & $\begin{array}{l}\text { Total score } \\
\quad(80)\end{array}$ \\
\hline Control (WF) & $8.40^{\mathrm{a}}$ & $8.15^{\mathrm{a}}$ & $8.32^{\mathrm{a}}$ & $17.32^{\mathrm{a}}$ & $17.65^{\mathrm{a}}$ & $8.25^{\mathrm{a}}$ & $68.09^{\mathrm{a}}$ \\
\hline \multicolumn{8}{|l|}{ WF: WBDP } \\
\hline $90: 10$ & $7.82^{\mathrm{ab}}$ & $8.00^{\mathrm{a}}$ & $8.00^{\mathrm{ab}}$ & $17.00^{\mathrm{ab}}$ & $17.80^{\mathrm{a}}$ & $8.00^{\mathrm{ab}}$ & $66.62^{\mathrm{ab}}$ \\
\hline $80: 20$ & $7.15^{\mathrm{abcd}}$ & $7.40^{\mathrm{ab}}$ & $7.15^{\mathrm{abc}}$ & $17.23^{\mathrm{ab}}$ & $16.90^{\mathrm{abc}}$ & $7.91^{\mathrm{abc}}$ & $63.74^{\mathrm{ab}}$ \\
\hline $70: 30$ & $7.07^{\mathrm{abcd}}$ & $7.15^{\mathrm{abc}}$ & $6.90^{\text {bcd }}$ & $16.41^{\mathrm{ab}}$ & $16.25^{\mathrm{bcd}}$ & $7.31^{\mathrm{abcd}}$ & $61.09^{\mathrm{c}}$ \\
\hline $60: 40$ & $6.00^{\text {cde }}$ & $6.33^{\mathrm{cd}}$ & $6.07^{\mathrm{def}}$ & $15.32^{\text {cd }}$ & $15.33^{\text {ef }}$ & $6.23^{\text {ef }}$ & $55.28^{\mathrm{d}}$ \\
\hline $\operatorname{SEM}^{\mathrm{B}}( \pm)$ & 0.45 & 0.31 & 0.36 & 0.39 & 0.46 & 0.35 & 1.80 \\
\hline
\end{tabular}

${ }^{a}$ Values for a particular column followed by different letters differ significantly $(\mathrm{p}<0.05)$; ${ }^{\mathrm{b}}$ Standard error of mean at 85 degrees of freedom.

\subsection{Conclusion}

Addition of wheat bran and date powder mixture to wheat flour affected the Rheological properties (farinograph and extensograph), Biscuit quality, physical properties, colour and sensory characteristics of biscuit. Highly acceptable biscuit could be obtained when $20 \%$ of wheat bran and date powder mixture was used in the formulation. The quality of biscuits was acceptable at level of $30 \%$. The dietary composition of these biscuits showed that fibres, which play a very important role, could be enriched in biscuits made from wheat bran and date powder. These studies have shown the potential of developing fibre-rich biscuits in order to increase the dietary fibre intake.

\section{REFERENCES}

[1] I. A. Ahmed, A. W. Ahmed and R. K. Robinson, "Chemical Composition of Date Varieties as Influenced by the Stage of Ripening," Food Chemistry, Vol. 54, No. 3, 1995, pp. 305-309. doi:10.1016/0308-8146(95)00051-J

[2] S. A. Al-Hooti, J. S. Sidhu, J. M. Al-Otibi and H. A.
Al-Ameeri, "Date Fortified with Almonds, Sesame Seeds, Oat Flakes and Skim Milk Powder," Plant Foods for Human Nutrition, Vol. 51, 1997, pp.125-135. doi:10.1023/A:1007959526896

[3] B. Lambiote, "Some Aspects of the Role of Dates in Human Nutrition," The First International Symposium on Date Palm, King Faisal University, Saudi Arabia, 23-25 March 1982.

[4] FAO, "Agriculture Data," FAOSTAT, Last Accessed May 2004.

http://faostat.fao.org/faostat/collections?subset=agriculture

[5] AO, "Dates," Food and Agriculture Organization of the United Nation, Rome, 2002, p. 391.

[6] C. J. Miller, E. V. Dunn and I. B. Hashim, "The Glycaemic Index of Dates and Date/Yoghourt Mixed Meals. Are Date the Candy That Grows on Trees," European Journal of Clinical Nutrition, Vol. 57, 2003, pp. 427-430. doi:10.1038/sj.ejen.1601565

[7] E. B. Saafi, E. Amira, I. Manel, H. Mohammed and A. Lotfi, "Phenolic Content and Antioxidant Activity of Four Date Palm (Phoenix dactylifera L.) Fruit Varieties Grown in Tunisia," International Journal of Food Science \& Technology, Vol. 44, No. 11, 2009, pp. 23142319. doi:10.1111/j.1365-2621.2009.02075.x

[8] W. N. Khatchadourian, J. K. Sawaya, W. M. Khalil and A. 
A. Mashadi, "Utilisation of Dates, (Phoenix dactylifera L.), Grown in the Kingdom of Saudia Arabia, in Various Date Products," The First Symposium on the Date Palm, King Faisal University, Saudi Arabia, 23-25 March 1982, pp. 504-518.

[9] H. Anwarul, U. Shams and A. Anwarul, "The Effect of Aqueous Extracted Wheat Bran on the Baking Quality of Biscuit," International Journal of Food Science and Technology, Vol. 37, 2002, pp. 453-462. doi:10.1046/j.1365-2621.2002.00583.x

[10] N. L. Kent and A. D. Evers, "Technology of Cereals," 4th Edition, Pergmon Press, Oxford, 1994, pp. 276-301. doi:10.1533/9781855736603.276

[11] A. M Hamad and A. K. Yousif, "Evaluation of Brine and Salt-Stock Pickling of Two Date Varities in the Kimri Stage," Proceeding of the Second Symposium on Date Palm, Saudi Arabia, 3-6 March 1986.

[12] F. R. Hussin, "The Measurement of Appearance," Wiley Interscience, New York, 1995.

[13] M. S. Mikki, W. F. Al-Tai and Z. S. Hamodi, "Industrialization of Dates and Development of New Products," The First International Symposium on Date Palm, King Faisal University, Saudi Arabia, 23-25 March 1983.

[14] R. C. Hoseney, "Principles of Cereal Science and Technology," American Association of Cereal Chemists (PUP), Pilot Knob Road, St. Paul, 1986, pp. 245-261.

[15] American Association of Cereal Chemists (AACC), "Approved Methods of the AACC," 10th Edition, St. Paul, Mn: 08-01, 44-15A, 46-10, 54-10, 54-21, 2000.

[16] AOAC, "Official Methods Analysis of AOAC," International Published by AOAC, Wilson Boulevard Arlington, Virginia, 2000.

[17] A. A. Paul and D. A. Southgate, "The Composition of Foods," 4th Edition, Elsevier North, Holland Biomedical Press, Amestrdam, 1979.

[18] C. S. Gains, "Instrumental Measurement of Hardness of Cookies and Crakers," Cereal Foods World, Vol. 36, 1991, pp. 989-994.

[19] J. M. Humpheries, R. D. Graham and D. J. Mares, "Application of Reflectance Colour Measurement to the Estimation of Carotene and Lutein Content in Wheat and Tritical," Journal of Cereal Science, Vol. 40, 2004, pp. 151-159. doi:10.1016/j.jcs.2004.07.005

[20] M. L. Sudha, R. Vetrimani and K. Leelavathi, "Influence of Fibre from Different Cereals on the Rheological Characteristics of Wheat Flour Dough and on Biscuit Quality," Food Chemistry, Vol. 100, No. 4, 2007, pp. 1365-1370. doi:10.1016/j.foodchem.2005.12.013

[21] D. B. Duncan, "Multiple Range and Multiple F-Test," Biometrics, Vol. 11, 1952, p. 42.

[22] R., Steel, J. Torrie and D. Dickey, "Principles and Procedures of Statistics; A Biometrical Approach (3rd Edition)," McGraw Hill Book Co., New York, 1996.
[23] Y. Pomeranz, M. D. Shogren and K. F. Finney, "White Wheat Bran and Brewers' Spent Grain in High Fibre Bred," Baker's Digest, Vol. 50, 1976, pp. 35-39.

[24] M. A. Jeltima, M. E. Zabik and L. J. Thiel, "Predication of Cookie Quality from Dietary Fibre Components," Cereal Chemistry, Vol. 60, No. 3, 1983, pp. 227-230.

[25] I. Baraem, H. Imad, B. Riad, M. Yehia and H. Jeya, "Physico-Chemical Characteristics and Total Quality of five Date Varieties Grown in the United Arab Emirates," International Journal of Food Science and Technology, Vol. 41, No. 8, 2006, pp. 919-926.

[26] C. L. Barber, C. B. Barber and J. A. Martinez, "Rice Bran Proteins II. Potential Value of Rice Bran Fractions as Protein Food Ingredients," Revista de Agroquinica Y Technology de Alementos, Vol. 21, 1981, pp. 247-258.

[27] Y. Pomeranz, M. D. Shogren, K. F. Finney and D. B. Bechtel, "Fibre in Bred Making-Effects on Functional Properties," Cereal Chemistry, Vol. 54, No. 1, 1977, pp. 25-41.

[28] C. M. Rosell, J. A. Rojas and B. Benedito, "Influence of Hydrocolloids on Dough Rheology and Bread Quality," Food Hydrocolloids, Vol. 15, No. 1, 2001, pp. 75-81. doi:10.1016/S0268-005X(00)00054-0

[29] T. E. Laurikainen, H. A. Harkonen, K. M. Autio and K. A. Poutanen, "Effects of Enzymes in Fibre-Enriched Baking," Journal of Science Food and Agriculture, Vol. 76, 1998, pp. 239-249.

doi:10.1002/(SICI)1097-0010(199802)76:2<239::AID-JS FA942>3.0.CO;2-L

[30] P. R. Lene, K. O Karl, N. S. Merete and A. D. Jens, "Rheological Properties of Biscuit Dough from Different Cultivars and Relationship to Baking Characteristics," Journal of Cereal Science, Vol. 39, No. 1, 2004, pp. 3746. doi:10.1016/S0733-5210(03)00064-X

[31] R. W. Jones and S. R. Erlander, "Interactions between Wheat Proteins and Dextrans," Cereal Chemistry, Vol. 44, 1967, pp. 447-453.

[32] B. M. Abd El-Lateef, "Production of Bakery Products Using Two Sources of Inulin," Annals of Agriculture Science, Moshtohor, Vol. 3, No. 1, 2003, pp. 61-378.

[33] H. A. Hashem, M. M. Abu-Fadl and A. G. Nassar, "Effect of Replacement of Wheat Flour by Jerusalem Artichoke Flour on Dough Rheological Properties and Quality off Biscuit Produced," Bulletin of the National Nutrition Institute, Cairo, Egypt, Vol. 25, 2004, pp. 198-218.

[34] B. Nermin, I. Senol and N. Emin, "Effect of Dietary Fibre Addition on the Selected Nutritional Properties of Cookies," Journal of Food Engineering, Vol. 72, 2006, pp. 339-345.

[35] K. E. Leelavathi and P. H. Rao, "Development of High Fibre Biscuits Using Wheat Bran," Journal of Food Science and Technology, Vol. 30, 1993, pp. 187-191. 